\title{
Folengo and Romanino: The Questione della Lingua and Its Eccentric Trends
}

\author{
Alessandro Nova
}

The works of the Brescian painter Girolamo Romanino (1484/87-1560) have attracted considerable critical attention during the last decade. ${ }^{1}$ We now know much more not only about his life but also about his network of patrons; some of his lost or previously unknown paintings have come to light; and four of his major fresco cycles have been restored, thus offering a unique opportunity to analyze his technique and working methods." Yet we will never understand his somewhat troubled career, which was marred by several controversies with his patrons, if we do not find a plausible answer to a major question: why did a very successful artist like Romanino, who in the early part of his career enjoyed the favor of the public and the support of powerful patrons (such as Nicolò Orsini, Francesco Gonzaga, the abbot Giovanni Cornaro, and the prominent Martinengo family), ${ }^{3}$ decide to move from what we now call a High Renaissance style, influenced by the works of Giorgione and Titian, to a more expressionistic, and indeed tormented idiom? What lay behind this apparently rebellious and probably socially disadvantageous choice-since later in his life he ended up working in such peripheral areas as the remote Valcamonica? Given the lack of written evidence to help shed light upon the painter's mentality and personality (for Romanino we have nothing comparable to either Lorenzo Lotto's or Jacopo Bassano's "account books"), there are no easy answers to these questions. A reasonable explanation of the artist's behavior, however, might have a bearing on our understanding of the entire group of Renaissance eccentrici, such as Altobello Melone, Giovanni Antonio Pordenone, Amico Aspertini, and Benedetto Diana, among others: that is, those heterodox artists who worked outside the High Renaissance mainstream in Northern Italy during the first four decades of the sixteenth century. ${ }^{+}$

The traditional characterization of these painters' oeuvres has been to emphasize their provincial, popular, or even vulgar nature, insofar as they did not conform to the "rules" of the High Renaissance classical canon as best exemplified in Northern Italy by Giorgione and Titian. ${ }^{5}$ By examining Romanino's anticlassical stand, however, the present writer would like to argue that such unclassical eccentricities were not necessarily addressed to provincial audiences; and that Romanino's dramatic change had more to do with stylistic self-consciousness than with networks of patronage (without implying by this statement that the social milieu in which the artist worked was irrelevant to or uninfluential on his formal choices).

The problem can be better understood if we approach this issue from a point of view that plays down the hierarchies constructed by our discipline, and if we try to learn from the results achieved in other fields of research, primarily the history of literature. Since the early 1980 s scholars have investigated artists such as Giorgione and Aspertini in the light of their "literary equivalents."6 Similarly, the present study aims to examine Romanino's works within the context of sixteenth-century heterodox literary experiments, and more specifically to investigate their relationship with the publications of the most gifted anticlassical writer of the period, the Benedictine monk Teofilo Folengo. The danger of such an undertaking is that paintings may be interpreted as mere reflections of other forms of art, thus substituting the rather vague notion of social background with a more fashionable but perhaps equally elusive "mirror." It is true that in a very broad sense one can argue that Folengo's works are the "literary equivalent" of Romanino's heterodox style, or vice versa, that the paintings of the Brescian artist are the "visual equivalent" of the writer's literary heterodoxy, but this does not take us very far. Instead, a detailed analysis of their possible relationship will highlight the cultural context of their similar intellectual goals and provide a framework for analyzing the social implications of their formal choices, since questions of style are densely packed with meaning that go well beyond what is normally taken as mere formalism.
A shorter version of this paper was discussed at the Center for the Arts of Weslevan Cniversity in April 1993. and at the Institute for Advanced Study in Princeton in December 1993. I would like to thank some of the participants for their helpful suggestions: Roma Goffen, Jeffres Hamburger. Irving Lavin. Marilyn Lavin, Laurie Naussdorter, John $\mathrm{T}$. Paoletti, and Wendy Stedman Sheard. My warmest thanks also to Philip Sohm for his generous insights. Translations throughout the essay are mine. 1. The most recent monograph on the artist is $\mathbf{M}$. L. Ferrari, Il Romanimo, Milan, 1961. See also the classic works br (i. Panara: Mostra di Girolamo Romanmo, exh. cat.. Brescia, 1965 (in collaboration with A. Damiani and B. Passamani): and Affreschi di Gerolamo Romanmo, Milan, 1965. More recent contributions include: A. Ballarin. "La Salomé del
Romanino: Corso di lezioni sulla giovinezza delpittore bresciano," Iniversita Statale di Ferrara, Facolta di Magistero, 1970-71 (ws in the Bibliotheca Hertziana in Rome); C. Boselli. Regesto artistico dei notai roganti in Brescia dall'anno 1500 ) all'anno 1560 . Brescia, 1977, 2 vols.; C. Cook. "The Lost Last Works by Romanino and Cambara," Arte lombarda, vols. LXX-1.XX1, 1984, 159-67; E. Chini, Gli affreschi del Romanmo nella loggia del Castello del Buonronsiglio a Trento, Milan, 1986; M. Gregori, ed., La pittura del Cinquerento a Brescia, Milan, 1986; A. Nowa, "Le ante dorgano di Santa Maria Maggiore a Trento." Studi trentini di scienze storiche. Sezione seconda, ixill. no. 1, 1988 [1984], 105-24; B. Passamani, ed., Romanimo in S. Maria della Neze a Pisognt, Brescia, 1991; Romanino in Santitntonio a Brmo. Breno, 1992; A. Ballarin, "Girolamo di Romano, dit Romanino," in Le Sierle de Titien: Lidge d'or de la peinture à Venise, exh. cat., Paris, 1993, $391-97$.

2. For his patrons and his previously unknown paintings, see the present author's forthcoming catalogue raisonné. Between 1985 and 1992 fresco cycles were restored in: the loggia in the Castello del Buonconsiglio in Trent, the chapel of Adeodata Martinengo in $\mathbf{S}$. Salvatore in Brescia, $\mathbf{S}$. Maria della Neve in Pisogne, and S. Antonio in Breno. For Romanino's technique and working methods, see V. Gheroldi, "Note su alcune pratiche di pittura murale," in Romanino in S. Maria della Neve a Pisogne, ed. B. Passamani, Brescia, 1991, 87-100; and V. Cheroldi, "Una ricerca sui livelli del finito," in Romanino in Sant Antomo a Breno (as in n. I), $77-105$

3. Furthermore, when the Cesuati commissioned him to execute the high alcarpiece for the church of 
1 Girolamo Romanino, Lamentation, 1510. Venice, Accademia (photo: Musei Civici di Brescia)

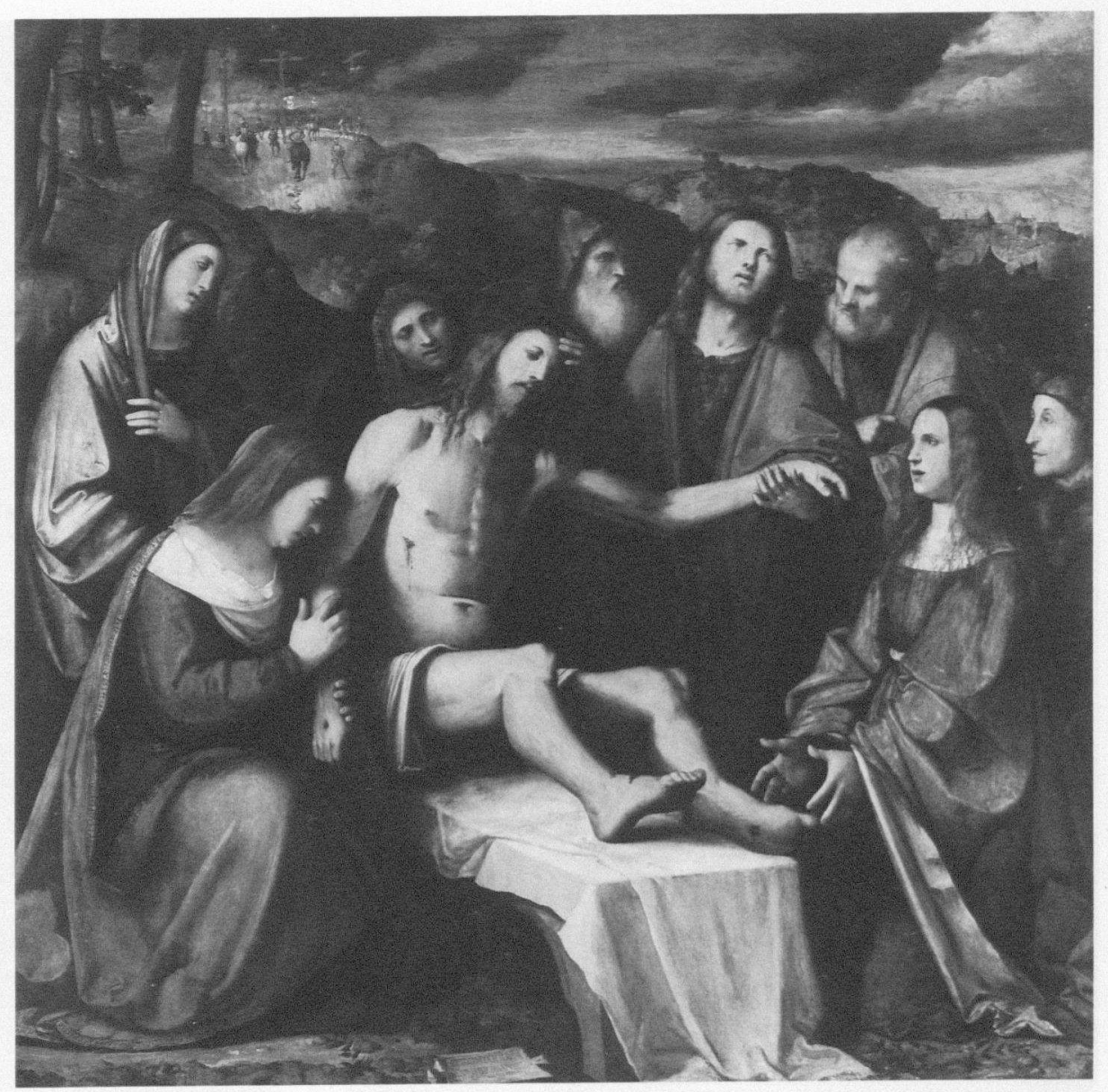

Let us compare two of Romanino's early altarpieces with one of his later panels. The Lamentation in the Accademia in Venice (Fig. 1), painted in 1510 for the Brescian church of S. Lorenzo, is a key work in his early career. The body of Christ, as stiff as a wooden sculpture, and the figure of Mary standing on the left-hand side are still Lombard elements indebted to the works of Bramantino and Zenale, but they are overwhelmed by High Renaissance Venetian features; indeed, the three male heads betray a close and prolonged study of Giorgione's works of around 1506, such as the Three Philosophers (also identified by some as the Three Magi); and the two Marys kneeling at the side of Christ are inspired by the paintings of the young Titian (e.g., the Madonna and
Child in the Accademia Carrara in Bergamo), as well as by Sebastiano del Piombo (e.g., his Salome in the National Gallery in London, also dated 1510). Of course, the early phase of Titian's career is highly controversial, and in principle one could object that we do not know enough about Titian at this stage to suggest that Romanino used his works as source material. Yet the present writer is inclined to agree with those scholars (most recently Alessandro Ballarin) who date the Jacopo Pesaro Presented to Saint Peter by Pope Alexander $V I$ in Antwerp to around 1506, the Fête champêtre in the Louvre to around 1509, the Madonna and Child between Saint Francis and Saint Roch in Madrid to around 1509-10, and the Saint Mark Enthroned for S. Spirito in Isola, now in S. Maria
S. Cristo in Brescia, the contract of Aug. 17, 1511 - the earliest surviving contract for one of his first major paintings - was drawn up in the sacristy of the monastery between the prior Oliverius and Romanino, who is described as "pictor excellens" (Boselli [as in n. 1], II, 81-82).

4. R. Longhi, "Cose bresciane del Cinquecento," L'Arte, xx, 1917, 104, was the first to outline the phenomenon of the Renaissance eccentrici. For an analysis of Longhi's contribution, see G. Romano, "Il Cinquecento di Roberto Longhi: eccentrici, classicismo precoce, 'maniera,'” Ricerche di storia dell'arte, no. 17, 1982, 5-27.

5. The traditional view is best summed up by $\mathrm{S}$. J. Freedberg, Painting in Italy, 1500 to 1600 (1971), Pelican History of Art, rev. ed., Harmondsworth, 1979. The first page (14) of chap. 1 of this ambitious book, which is still much used in classrooms, deals with a definition of the classical style in the different regions of the Italian peninsula: "The most extraordinary intersection of genius art history has known occurred then [in the 16th century's first two decades in Florence and Rome] and gave form to a style which, again eliciting a term that is a value judgement, we call 'classic' or 'classical'.

With less emphasis this applies elsewhere in Italy through the 16th century's extent. In Venice the first years of the Cinquecento had seen the invention of a style which in more essential principles resembled that of the contemporary Florentines. The Venetian variant of High Renaissance classicism endured longer than its counterpart in Central Italy and assumed, in the territories relevant to Venice, a comparable authority." Freedberg's text is also paradigmatic for his characterization of bello Melone: at times Pordenone created deliberately violent and vulgar images "for the purpose of making communication with a popular and provincial audience" (291, 297); Romanino's frescoes in Valcamonica resemble "the earlier, inchoate, popolano Pordenone" in their "popular verism" (365); Altobello Melone's figures are "given a deliberately unbeautiful Germanic cast" (375).

6 . For the useful notion of "literary equivalent," see Romano (as in n. 4), 6, 14, 16, 22, who interprets the language of the Bolognese humanist Codro as the corrispettivo letterario of Amico Aspertini's works. For Giorgione, see A. Ballarin, "Giorgione e la Compagnia degli Amici: Il 'Doppio ritratto' Ludovisi," in Storia dell'arte italiana, pt. 2, I (5), Dal Medioevo al Quattrocento, Turin: Einaudi, 1983, 479-541. 


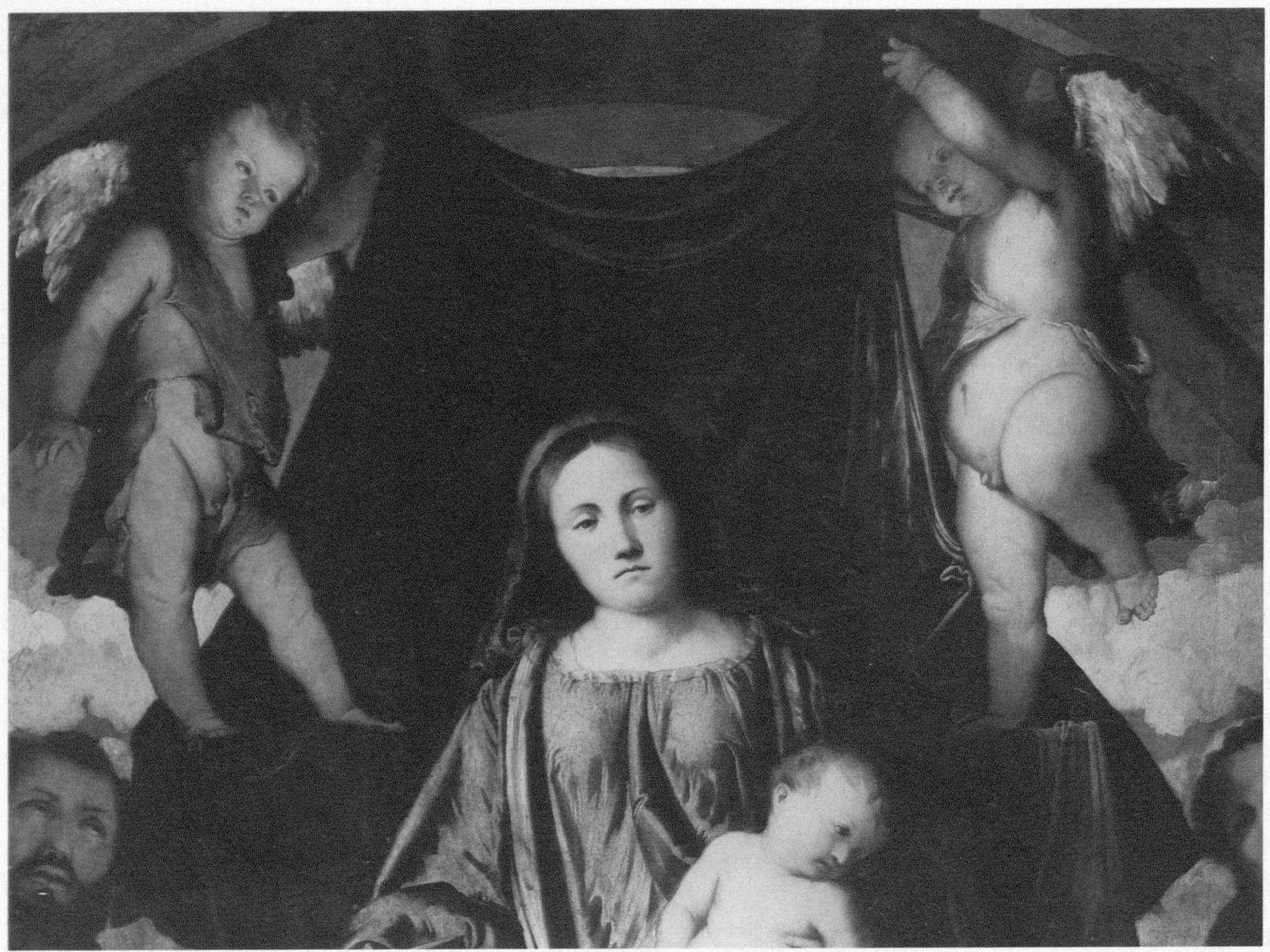

2 Romanino, Madonna and Child with Saints (detail), 1516-17. Brescia, S. Francesco (photo: Musei Civici di Brescia)

della Salute, to around $1510 .^{7}$ Regardless of the dating and attribution of many controversial pictures, the new visual language that Giorgione and his immediate followers created during the first decade of the sixteenth century was in any case publicly accessible on the walls of the Fondaco dei Tedeschi, frescoed by Giorgione and by Titian in 1508-9, and this is clearly what the Brescian artist studied intensively during his first visits to Venice. Titian's work became an even more emphatic point of reference during Romanino's Paduan exile (ca. 1513-14), as the altarpiece for S. Giustina in Padua shows, and that its influence continued unabated after Romanino's return to Brescia is demonstrated by his high altarpiece for S. Francesco, painted in 1516-17: in it, references to Lotto's Martinengo altarpiece (installed on the high altar of the Dominican church in Bergamo in 1516) are clearly visible in the faces of the saints, but the angels, the Madonna's face (Fig. 2), the colors, and the saints' robes in the foreground are all elements inspired by the works Titian produced during the $1510 \mathrm{~s}^{8}$ Although the following decades of Romanino's career are marked by occasional returns to Titianesque formulas (as in his polyptych painted for the Brescian church of S. Alessandro in 1524-25 and now in the
National Gallery of Art in London), his heterodox tendencies manifested themselves in 1519-20, when he was invited to contribute to the celebrated fresco cycle in the nave of Cremona Cathedral.

The extent of this transformation from what we may call, admittedly in rather schematic terms, a classical to a more heterodox, anticlassical vocabulary is well illustrated by Romanino's impressive Resurrection, painted around 1526 for the town of Capriolo (Fig. 3). A comparison of his altarpiece with the central panel of Titian's Averoldi polyptych (Fig. 4), which was installed on the high altar of S. Nazaro in Brescia in 1522, makes clear that the Brescian artist was no longer mesmerized by the works of his colleague: Romanino obviously had studied the Averoldi polyptych before executing his painting, so much so that the cuirass of the soldier seen from the back, as well as the dawn light, is taken directly from the Titian prototype, but the way in which the imposing figures are arranged around the minuscule sarcophagus, the awkward anatomy, and the soldiers' faces are almost a parody of Titian's work.

Similar features are apparent in Romanino's fresco cycles. The fragmentary frescoes for the loggia of Nicolò Orsini at exh. cat., Venice, 1990, 135-40, 148, 151-52; and Ballarin (as in n. 1), 316-23, 340-48, 348-51. 8. The best and most detailed analysis of the influence of Titian's work in Romanino's percorso during the first two decades of the 16 th century is in Ballarin (as in n. 1), passim. 


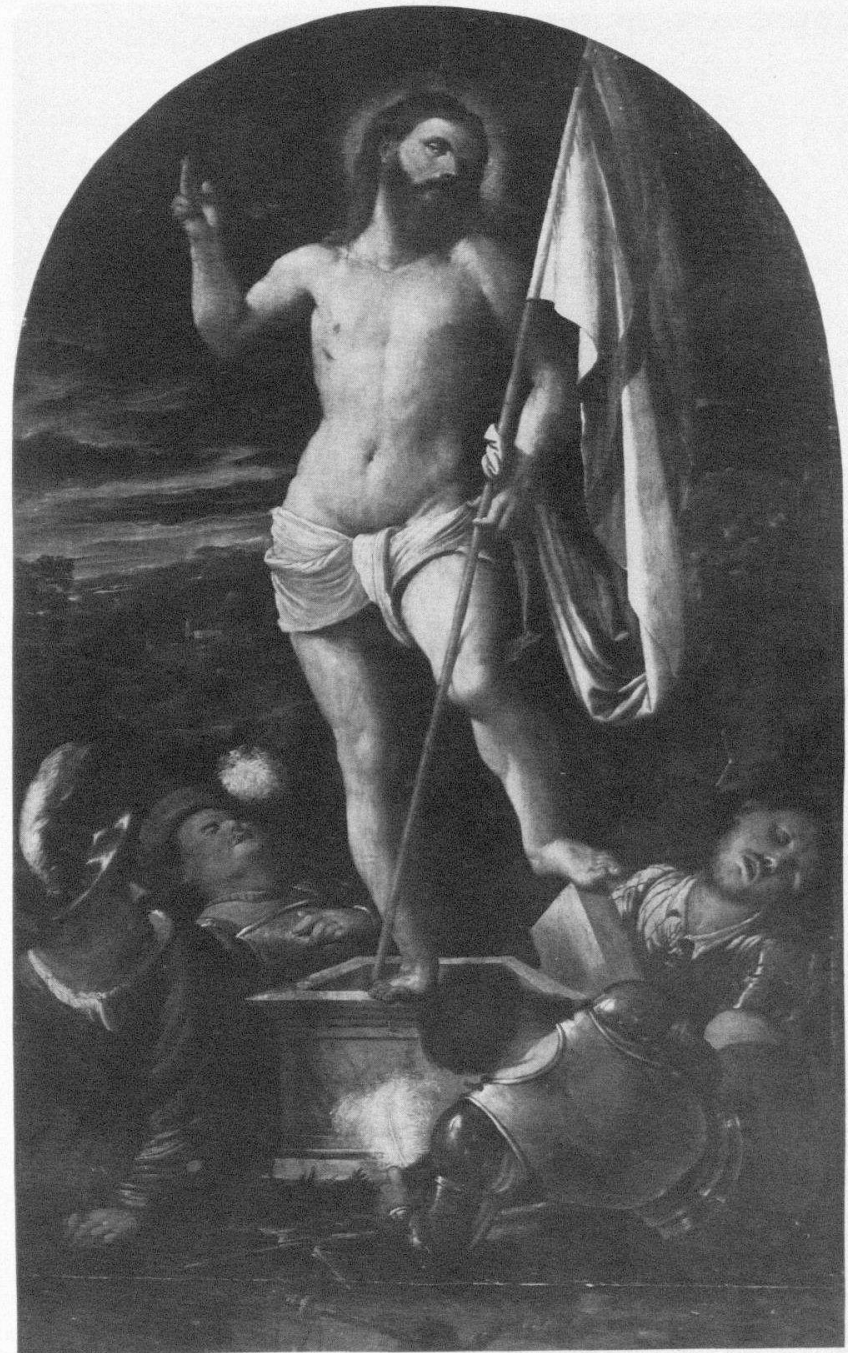

3 Romanino, Resurrection, ca. 1526. Capriolo, parish church (photo: Musei Civici di Brescia)

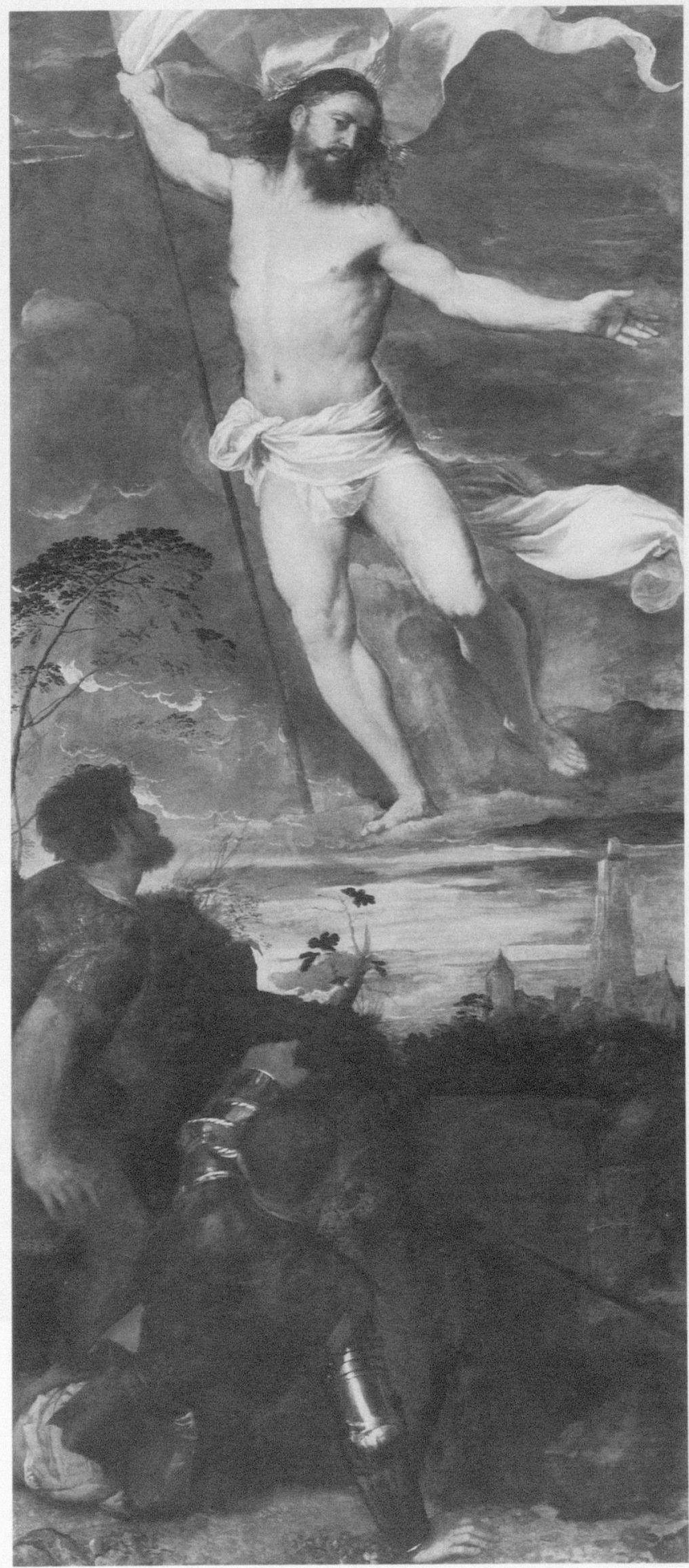

4 Titian, Resurrection, 1520-22. Brescia, Ss. Nazaro e Celso (photo: Musei Civici di Brescia) 


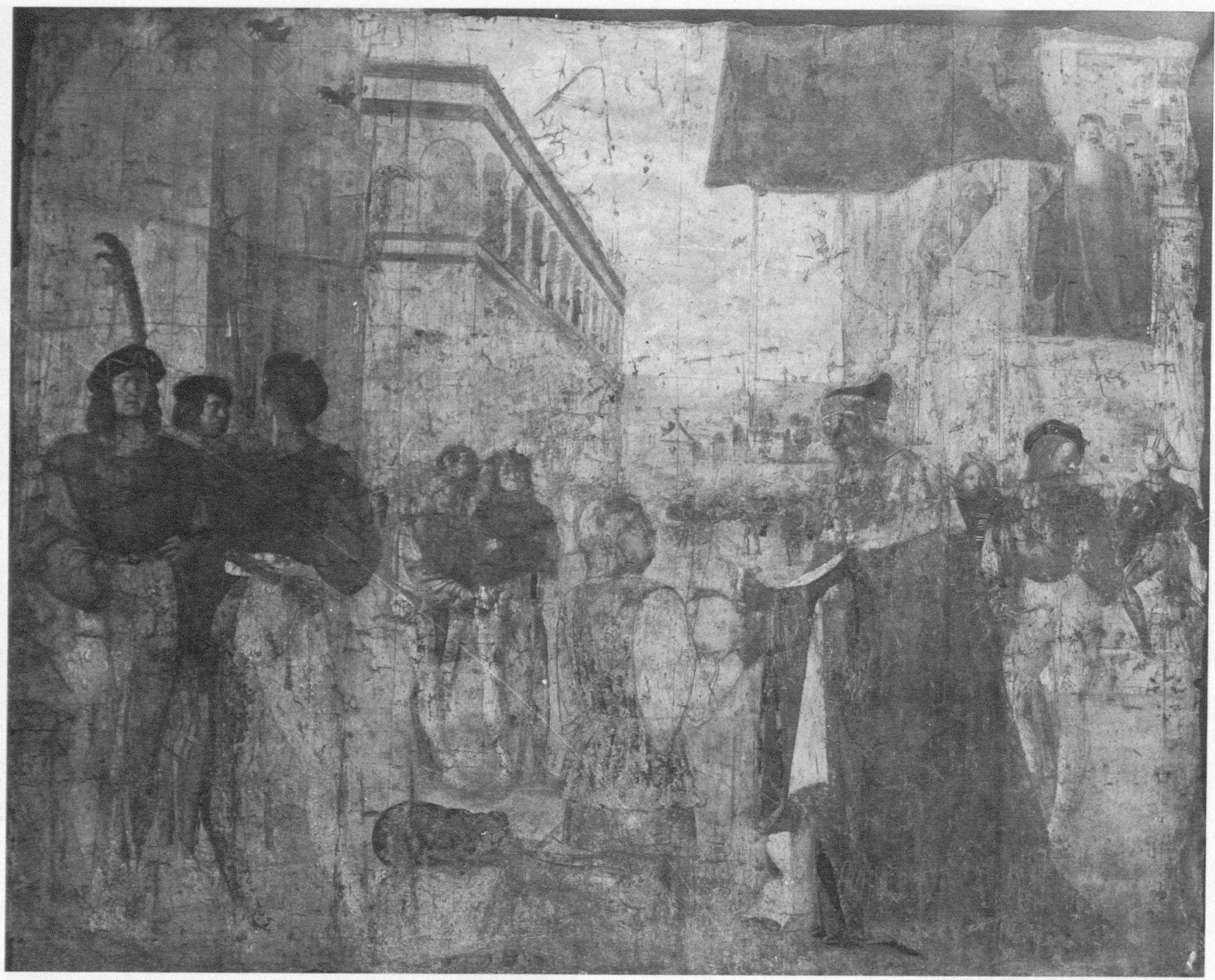

5 Romanino, Nicolò Orsini Receiving the Banner from the Doge of Venice, ca. 1508-9. Budapest, Szépmüvészeti Múzeum (photo: Szépmüvészeti Múzeum)

Ghedi (Fig. 5), executed in 1508-9 and now in Budapest, demonstrate an accomplished blend of Lombard and Venetian elements, their Bramantinesque buildings and Giorgionesque figures painted in a truly High Renaissance style. By contrast, Romanino's Venetian repertoire becomes more dramatic and eccentric in the spectacular Passion scenes he frescoed in the nave of Cremona Cathedral in 1519; indeed, in the scene representing Christ crowned with thorns (Fig. 6), the classical architecture and the Giorgionesque "dandy" in the middle ground clash with the violent expressionism of the figures in the foreground, the latter inspired by Northern European prints. Northern prints provided the rhetoric of a more dramatic and almost violent style, and they were frequently consulted by heterodox artists in Renaissance Lombardy ${ }^{9}$
It is interesting to note, however, that Romanino never quoted his sources directly; rather, he cast these German characters in his own original context for the purpose of creating a grotesque visual language which reached its peak in the audacious frescoes painted in S. Antonio at Breno (Valcamonica) in the late 1530s (Fig. 7).

This dramatic stylistic change cannot be explained only in terms of different subject matters and/or different audiences. Indeed, when in 1531-32 Romanino was commissioned to fresco several rooms, corridors, and a loggia in the palace of Cardinal Bernardo Clesio, the so-called Castello del Buonconsiglio in Trent, with secular themes, the artist by no means eliminated such heterodox experimentations from his vocabulary. Moreover, Romanino also seized the opportunity of introducing his new and rather disconcerting visual 


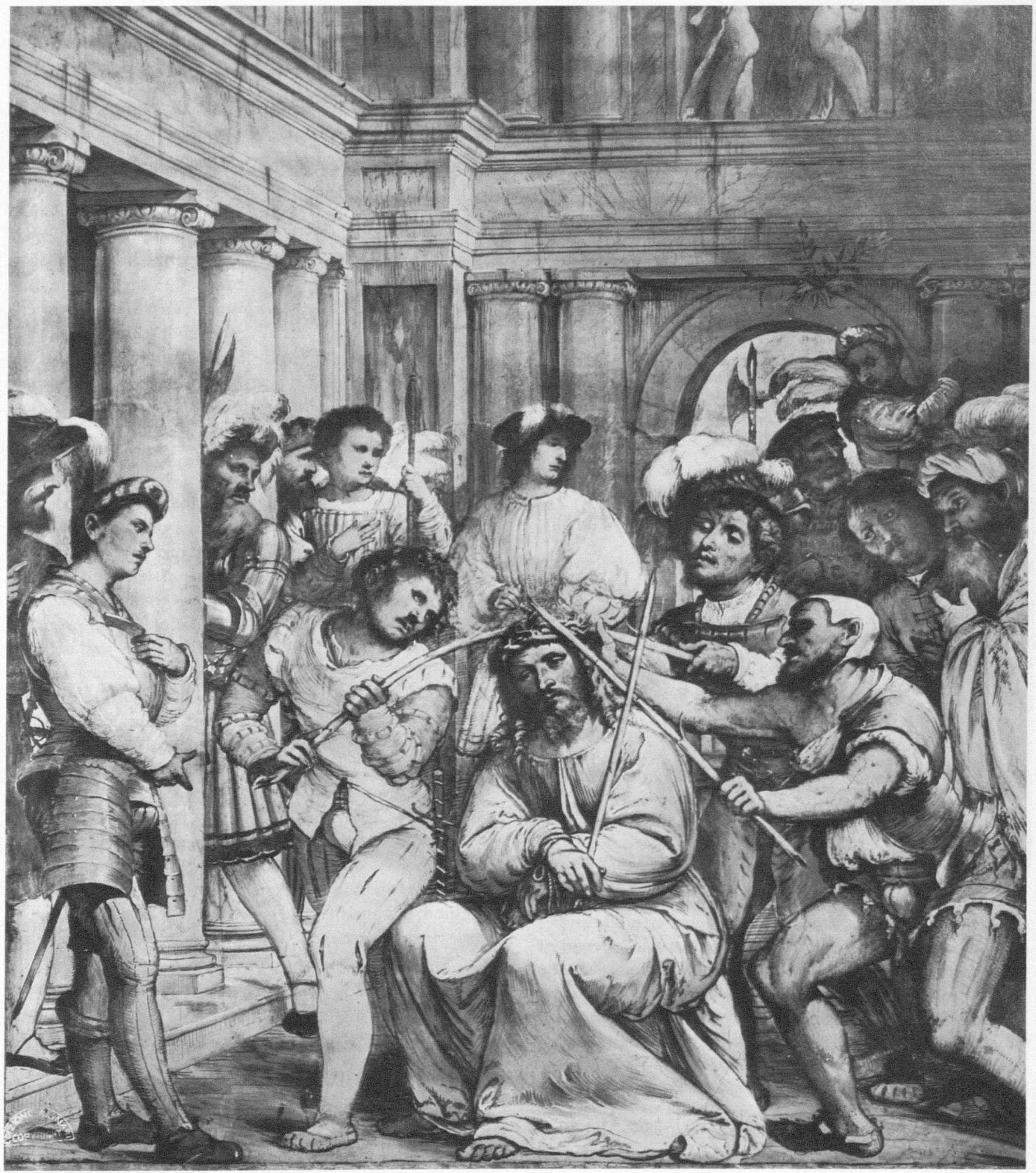

6 Romanino, Christ Crowned with Thorns, 1519. Cremona, Cathedral (photo: Musei Civici di Brescia, Edizione Alinari) 


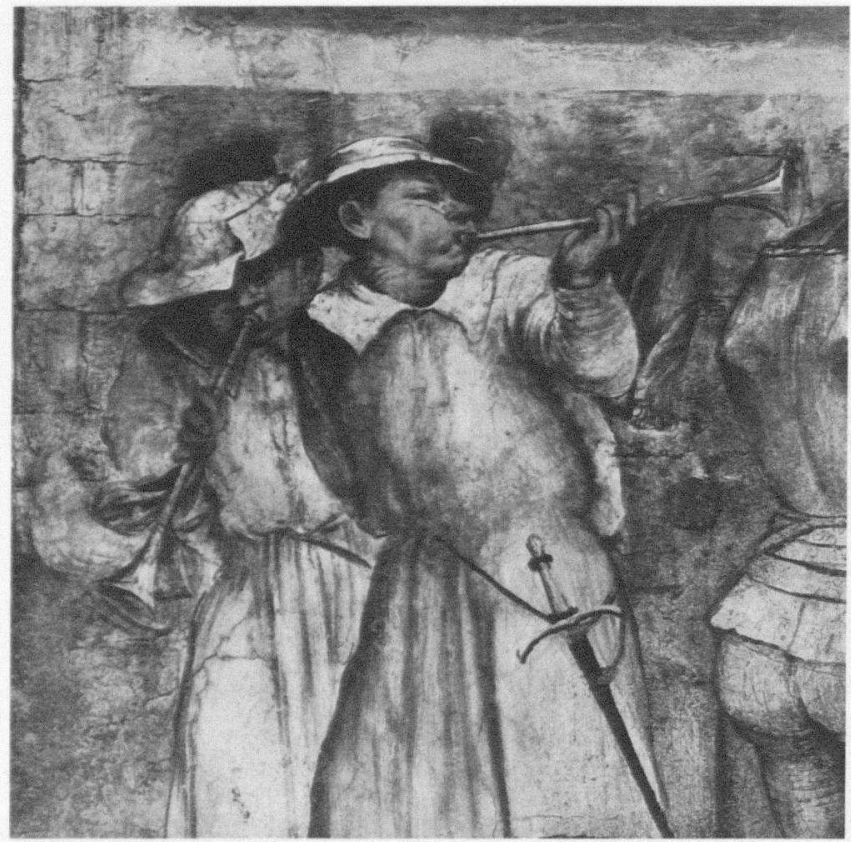

7 Romanino, Two Soldiers (detail of fresco cycle), ca. 1536-37. Breno, S. Antonio (photo: Musei Civici di Brescia)

language into his own native Brescia, as his Pentecost in S. Francesco shows (Fig. 8). This frescoed altarpiece was painted in 1520 for the church where three years earlier Romanino had executed his Titianesque panel for the high altar. $^{10}$

We cannot, therefore, explain the stylistic change that occurred in his works around 1519-20 exclusively in terms of different media, different subject matter, or different audiences. Some of these factors might have played a role in each single commission, but this change seems to have been the result of mainly if not purely formal choices.

In their discussion of Romanino's paintings scholars have frequently drawn attention to this dramatic shift in style, but to date no plausible explanation for the change has been put forward. To explain it in the traditional narrative terms of the provincial artist no longer capable of maintaining the pace of a great master seems inadequate, primarily because the vigor of the painter's heterodox works cannot be called into question: they may be "written" using a different vocabulary - if not a different grammar-but they are still very impressive paintings. Romanino's works from 1519-20 onward, therefore, should not be interpreted as the result of a period of crisis, in the negative sense of the word, as though they had been created by a painter uncertain of the direction of his artistic commitment; rather, they should be seen as a conscious critique of the North Italian High Renaissance canon. In the absence of written evidence documenting Romanino's own stance on this issue, such an interpretation must, of course, remain speculative; nevertheless, a few clues do exist, and these point to an encounter which might have played an important role in his artistic career. The purpose of this article is to investigate Romanino's possible contact with the Benedictine monk Teofilo Folengo, who frequented the same network of patrons; and to show how that connection might provide an explanation for the dramatic stylistic change in Romanino's later works. Before we examine their respective careers, however, it is necessary to discuss briefly an issue which was furiously argued among literary circles of the Italian peninsula during the first three decades of the sixteenth century: the questione della lingua, or the debate about the selection and/or creation of a national literary language.

Historians of Renaissance literature have invariably regarded the complex questione della lingua as a crucial stage in the history of Italian culture, and it is a phase that has been extensively debated. The different literary approaches framing this fundamental question have been described as classical, cortigiano, or decidedly heterodox - that is, anticlassical. In a discussion of Renaissance art, therefore, it is appropriate to employ the same terminology and thus refer to classical or anticlassical styles in painting. As far as the literary scene is concerned, the period concluded with the success of Pietro Bembo's theories as expounded in his celebrated Prose della volgar lingua. Although Bembo had already completed part of the text as early as 1512 , his book was not published until 1525. ${ }^{11}$

The Venetian humanist was a key figure in this troubled period, not only because he embodied all the qualities and shortcomings - that is, all the contradictions of his epochand not only because he established the canon for the entire question; but also because he was himself an attentive, albeit somewhat indiscriminate collector, an admirer of Michelangelo, Raphael, and Giorgione, and a habitué of artistic circles. ${ }^{12}$ We find Bembo everywhere: at the courts of Ferrara, Urbino, and Rome; in Venice, where he was born; and in Padua, where he often stayed between 1520 and 1524 while he was writing out the Prose. He is mentioned in numerous letters and literary works, such as Castiglione's Cortegiano and Benvenuto Cellini's autobiography, often as in direct contact with artists. Cellini, who was his guest in Padua when en route to the court of Francis I of France, was
10. Although two works in two different media are being compared, and although fresco painting allows a greater freedom of expression, both these works functioned as altarpieces in the same church and, as we have seen, Romanino's frescoes for Nicolò Orsini were painted in a High Renaissance style very different from the style used by the artist in frescoing the Pentecost.

11. On Pietro Bembo and the questione della lingua, see C. Dionisotti: "Bembo, Pietro," in Dizionario biografico degli italiani, VIII, Rome, 1966, 133-51; idem, intro. to Prose e rime (1966), repr. as Prose della volgar lingua. Gli Asolani. Rime, Turin, 1989 idem, Geografia e storia della letteratura italiana, Turin, 1967; and Dionisotti. See also M. Tavoni, "Prose della volgar lingua di Pietro Bembo," in Letteratura italiana: Le Opere, I, Dalle Origini al Cinquecento, Turin: Einaudi, 1992, 1065-88. For general surveys on the questione and an up-to-date bibliography, see B. T. Sozzi, Aspetti e momenti della questione della lingua, Padua, 1955; B. Migliorini,
Storia della lingua italiana (1960), 6th rev, ed., Florence, 1983; M. Vitale, La questione della lingua (1960), rev. ed., Palermo, 1978; B. Migliorini, The Italian Language (1966), rev. ed. T. G. Griffith, London, 1984; and A. Stussi, Lingua, dialetto e letteratura, Turin, 1993

Approaches to this crucial question were, of course, extremely varied. In addition to Bembo's proposal that the early Tuscan writers (Petrarch for poetry and Boccaccio in prose works) be imitated and the anticlassical claim to an unprejudiced 


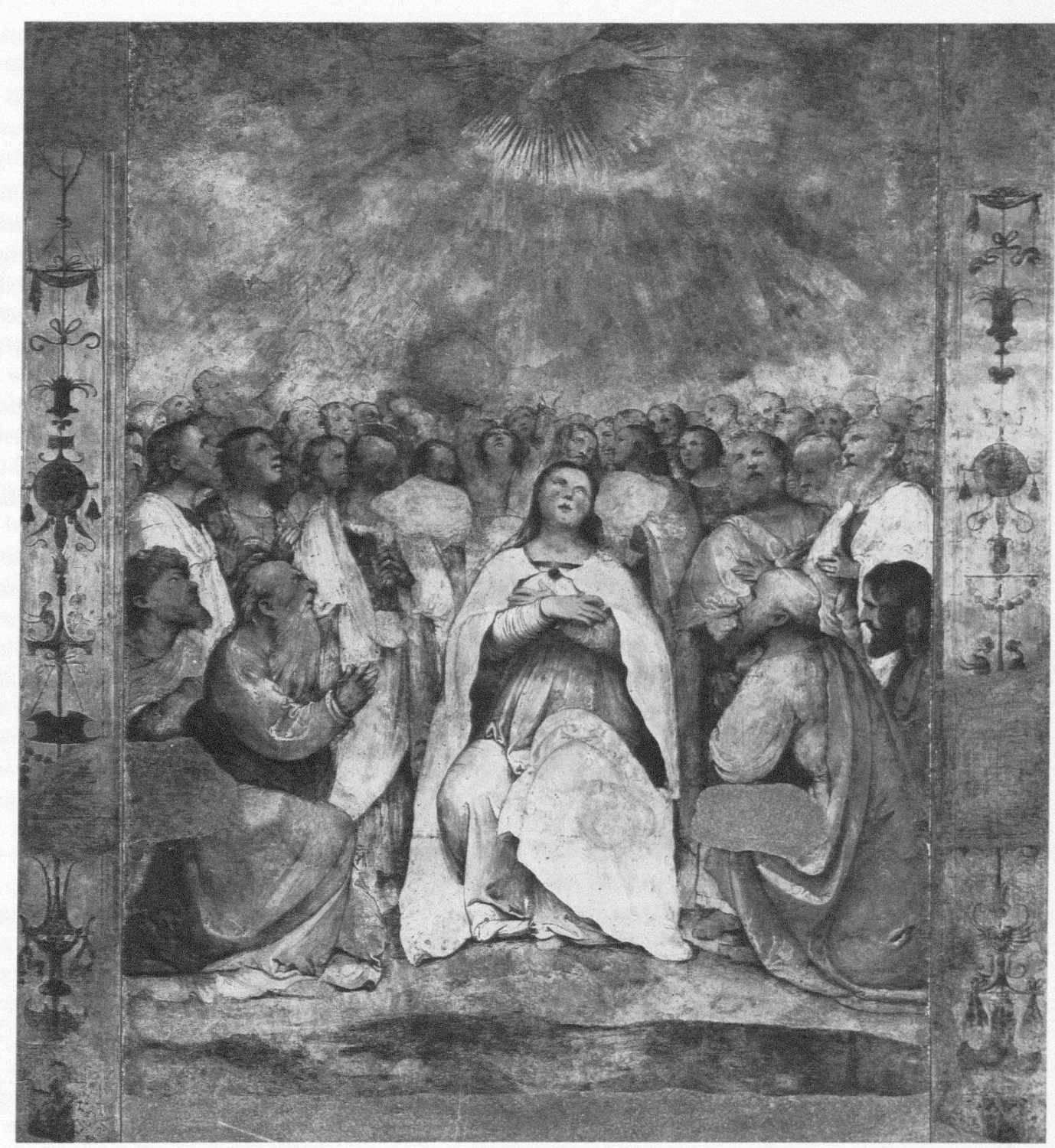

8 Romanino, Pentecost, ca. 1520. Brescia, S. Francesco (photo: Musei Civici di Brescia)

rather critical of Bembo's artistic taste but he praised his magnanimity as well as his unchallenged expertise in poetry and literary matters in general. ${ }^{13}$ Equally interesting and perhaps less well known is a novella by Matteo Bandello, in which Bembo and Matteo Navagero fall victim to a prank organized by the painter Girolamo da Verona. When the deception is finally revealed, Bandello records how "Navagero berated himself for not having recognized him [the artist Girolamo dressed up as an obnoxious relative of Bembo] since in Venice and Verona the painter was in close contact with both him and Bembo."14
For a figure such as Bembo, who was personally acquainted with many artists, it would have been impossible to ignore the connection between the literary questions of his time and the question of visual language: they were complementary aspects of the wider cultural debate of the period, which itself was concerned with and also partly determined by the crisis of the Italian political system. Given this intellectual climate, it is difficult to believe that cultivated artists such as Giorgione and Gian Cristoforo Romano, for example, were unaware of what was then being discussed in Venetian humanistic circles or at the court of Mantua: linguistic freedom, one should at least mention the self-serving position of Claudio Tolomei, Pier Francesco Giambullari, and Benedetto Varchi, who argued in favor of the modern (i.e., 16th-century) Tuscan language, and the supporters of eclectic solutions (the lingua cortigiana), such as Vincenzo Colli called Il Calmeta, Mario Equicola, Angelo Colocci, and Giovanni Filoteo Achillini. Baldassarre Castrglione also contributed to this disctssion, notably in his Il Cortegiano, in which he criticized Bembo as well as those who favored the use of the modern Tuscan language ("Proemio," chap. 2) and proposed a unified Italian language (bk. 1, chap. 35).

12. On Bembo's admiration for Giorgione, see T.Pignatti in J. Martineau and C. Hope, eds., The Genius of Venice, London, 1983, 29. Raphael and Michelangelo are mentioned in bk. 3, chap. 1 of his Prose (ed. Dionisotti, 1989 [as in n. 11], 183-84). On Bembo's collection, see S. Eiche, "On the
Dispersal of Cardinal Bembo's Collection," Mitteilungen des Kunsthistorischen Institutes in Florenz, XXVII, 1983, 353-59.

13. Opere di Baldassare Castiglione, Giovanni Della Casa, Benvenuto Cellini, ed. C. Cordié, Milan/ Naples, 1960, 700-2

14. M. Bandello, Novelle, ed. G. G. Ferrero (1974), Turin, 1978, 493: "Il Navagero si disperava di non averlo conosciuto, perché e in Vinegia e in Verona esso pittore a lui e al Bembo era molto domestico. 
indeed, we know that the sculptor even bequeathed his own copy of Bembo's Asolani to his notary. ${ }^{15}$ It is probable, therefore, that artists followed this debate with interest, and that the visual arts played an equally important role in defining the new canons of artistic expression.

It should not be forgotten, however, that the undeniably successful response to Bembo's theories in part also succeeded in eliminating the traces of a debate that had dominated the intellectual life of the Italian peninsula for over a quarter of a century. In other words, that the animated querelle about the language gave shape to a great number of different theoretical proposals (which were later buried by the success of "the Bembo way") should not be overlooked. Far from celebrating the indisputable triumph of the High Renaissance, the first decades of the sixteenth century witnessed an exciting plurality of different experiences, and in the visual arts similarly conflicting views were also apparent. For this reason an analysis of the questione della lingua from the so-called anticlassical viewpoint can be valuable also with regard to the visual arts.

While it is unnecessary to devote too much time to the questione from the viewpoint of the classical positionalready extensively studied-it is important to bear in mind a few essential data and an important suggestion. First, the issue of establishing an Italian national language evolved during the last two decades of the fifteenth century, reaching its most vital and critical stage during the first quarter of the sixteenth century. Second, Bembo had already articulated his views well before the publication of his Prose, as demonstrated by his editions of Petrarch's Rime (1501) and Dante's Commedia (1502), both published by Aldus, as well as by a letter, dated September 2, 1501, in his correspondence with Maria Savorgnan. ${ }^{16}$ Finally, from 1525 to 1530 , after the great success of the Prose, Bembo worked hard to establish the supremacy of a new vernacular literature, but before then there had been room for a number of alternative experiences.

The suggestion comes from a passage by Carlo Dionisotti:

Those scholars who study the literary history of these few but crucial years, when the Ciceronian polemic coincided with the writing of the Principe and the Furioso, the Prose and the Cortegiano, cannot help asking which came first: the chicken or the egg: In other words, whether the impetus of the new literature put the old one in a critical position, or whether the crisis of the old literature gave impetus to the new. It is certain that the sources available to us are tightly interwoven so that either hypothesis is feasible. And the historian can do no other than accept the documents in the order in which they have been preserved. ${ }^{17}$

This passage refers to the contrast between the declining Latin Humanism and the demand for a renewed literary instrument, but it is also pertinent in that it sheds light on the many proposals concerning the development of a vernacular language and helps to distinguish these proposals from the heterodox formal experiments of a different Renaissance. Indeed, Dionisotti's concern for an accurate analysis of the chronology involved is also important for an analysis of the so-called anticlassical experiments, because in the delicate comparative study of art and literature we must avoid the trap of attributing purely mechanical and sometimes only presumed relationships.

Given these provisos, the following pages will analyze the literary works of the Benedictine monk Teofilo Folengo within the context of the questione della lingua. The reason for this study is that Folengo was the quintessential anticlassical writer; and his masterpiece, Baldus, originally published in 1517, can perhaps further our understanding of the more profound reasons behind the stylistic change evident in the works of Romanino-a change which evolved during the same period and, what is more important, in the same social ambience.

The linguistic dilemma troubling Italian intellectuals at the end of the fifteenth and the beginning of the sixteenth centuries created an unstable but enormously rich cultural environment in which extremely diversified-and daringexperiments were conducted. The city of Mantua, where Folengo was born and where the Tuscan language had never been popular, was particularly open to linguistic experimentation. Similarly, nearby Padua became the capital of the plurilinguistic tradition of Italian literature, ${ }^{18}$ and the socalled macaronic style of poetry developed in Padua largely because of that city's exceptionally favorable cultural environment. Here, audacious linguistic experiments could find nourishment in the "rustic" texts of the fifteenth-century Veneto, in the brilliant university world which promoted masquerades and theatrical pantomimes in dialect form, and in the colorful mixed language used by the professors, such as the Aristotelian Pomponazzi, who taught in the Studio (the local university). ${ }^{19}$
15. G. Romano. "Verso la maniera moderna: Da Mantegna a Raflaello," in Storia dell'arte italiana, pt 2. II $\left(6^{*}\right)$, Cinquecento o Seirento. Turin: Einaudi. 1981,63 .

16. Aldus had published only two vernacular texts before his edition of Bembo's Rime: Hypnerotomachia Poliphili (Dec. 1499) and Saint Catherine's Epistole 1O(t. 1500). For Bembo's love letters, see M. Savorgnan and P. Bembo, Carteggio damor" (150)-1501), ed. C. Dionisotti, Florence, 1950.

17. Dionisotti, 111

18. For Mantua, see Dionisotti, $78-130$; G. Ghinassi. "Il wolgare mantovano tra Medioevo Rinas- cimento," in Ludotico Ariosto: Lingua, stile e tradizione. Atti del congresso di Reggio Emilia e Ferrara (1974), ed. C. Segre, Milan, 1976, 7-28; (;. M. Anselmi, L. Avellini, and E. Raimondi, "Milano, Mantova e la Padania nel secolo XVI," in Letteratura italiana: Storia e geografia, in, pt. 2, L'eti moderna, Turin: Finaudi, 1988.593-618. For the role played by Padua as the capital of the plurilinguistic tradition of Italian literature, see Paccagnella.

19. B. Nardi. Studi su Pietro Pomponazzi, Florence, 1965.

20. Among the best macaronic poets were the Paduan Corado, Tifi Odasi and the anonvmous author of the Nobile Vigonce Opus, the Mantuan
Bassano, and the Cremonese Fossa who wrote the Virgiliana (1494): the latter, usually identified as Matteo Fossa, was probably the Servite friar Evangelista Fossa (see G. Padoan, "Alcune considerazioni sulla 'scuola' maccheronica padovana," in Cultura, 298-99). On the Paduan origins of the macaronic language, see I. Paccagnella, Le macaronee padovane: Tradizione e lingun, Padua, 1979; and idem, "Origini padovane del macaronico: Corado e Tifi," in Storia della cultura veneta: Dal primo Quatrocento al Comcilio di Trento, w1/1, Vicenza, 1980, 413-29.

21. R. Garyia, "I sermoni maccheronici del Quattrocento," Annali della facolta di lettere dell' Unizersitò 
One should not be surprised that the most daring linguistic experiments took place in the same city where a few years later Bembo was to write out his milestone of the classical canon, since it is likely that it was this strong anticlassical tradition which inspired the humanist's reaction to it. Indeed, we know that after its uncertain and undocumented beginnings in the area between Lombardy and the Veneto, macaronic poetry became a true form of art in Padua. Here Tifi Odasi, one of Folengo's main sources of inspiration, was active. ${ }^{20}$ Tifi Odasi's language was greatly influenced by the inventive lexical combinations of contemporary preachers, such as Bernardino da Feltre, but in Folengo's hands the macaronic mixture was no longer associated with the latinus grossus of preachers and notaries that had been used and transformed by his predecessors. ${ }^{21}$ With Folengo macaronic language lost part of its ludic character, thus developing into a sophisticated weapon in his struggle against the linguistic canon established by Pietro Bembo. ${ }^{22}$ While there remain many unresolved questions concerning the Benedictine monk, whose personality is open to contrasting interpretations, all those who have recently examined his literary works agree on one essential point: Folengo's audacious linguistic experiments were not merely a playful stylistic game, but concealed a consciously anticlassical stand in defence of the rich and multiple expressive resources of North Italian culture.

It is virtually impossible to grasp the power of Folengo's creative language without reading his poem, but a translation of the incipit of Baldus should be sufficient to give a taste of his linguistic experiments as well as an idea of his scatological, Rabelaisian themes:

The most fantastic fantasy came to my mind,

To sing the story of Baldus with my fat and coarse Camene [the Muses of macaronic poetry].

The fame of Baldus is so great and his very name so strong

That the earth shakes and the abyss of hell shits with terror.

But before I begin, I must call for your help,

O Muses who bestow the macaronic poetry. ${ }^{23}$

The crudeness of Folengo's scatological verses is usually softened by his irony. But we should not be misled by his playful tone because, as in Rabelais, the farce conceals very serious matters. ${ }^{24}$ Indeed, in his prefaces to the many editions of Baldus Folengo was quite open in expressing his dissent from Bembo's views. And it is in this context that Dionisotti's emphasis on the necessity of establishing a precise chronological sequence becomes most pertinent.

The first edition of Baldus was printed without illustrations by Alessandro and Paganino Paganini in January 1517 (or 1518 if the date is interpreted more veneto). However, Folengo's polemic assumed a more conscious form between this first incomplete version and the second edition: the latter is known as the toscolanense because it was published in 1521 at Toscolano, on Lake Garda, again by the Paganini. These were the most serene and productive years of Folengo's career, and it was during this period that the poet, then not yet thirty years old, became fully aware of his own linguistic experimentation. In this second enlarged edition, illustrated with fifty-four woodcuts, the author defends the great expressive flexibility of the macaronic language in his celebrated "Apologetica in sui excusationem." Here Folengo hints at the criticism his first edition had received, but he also goes so far as to claim the creative rights of any language. He thus appears to share a view strikingly similar to the ideas expressed by the philosopher Pomponazzi, whom Folengo described in his fictional autobiographical profile as his teacher. ${ }^{25}$ The message of the "Apologetica" was repeated and expanded in Folengo's Orlandino, published in Venice in 1526 immediately after the monk's dramatic-albeit temporary-exit from the Benedictine order. Here Folengo claims that he cannot and does not want to apologize to his learned readers for the blatant mistakes "in his use of the elegant Tuscan language, because nature has eliminated this language from Lombardy, where it is not taught." 26 An acid reference to Bembo's Prose, published the year before, is obvious. In the first chapter of Orlandino the monk also writes: "Yet you must know that I am Lombard . . , but I do not lament because I was not born in Tuscany." 27 In 1527 Folengo reaffirmed this concept in his Caos del Triperuno, in which Merlino scolds Limerno (the anagram makes it clear that we are dealing with two disguised components of the poet's own personality, since Merlino is the fictitious author of Baldus) for having fallen. like many others, into the trap of the Tuscan canon. ${ }^{2 *}$ Finally, Folengo makes his position even more explicit in the third edition of Baldus (the so-called cipadense from the fictitious place of publication, Cipada), which was printed around 1540, approximately four years before his death. Here the poem is followed by an appeal to the readers written by a certain Nicolò Costanti (who is really yet another of Folengo's endless disguises). Of course, Costanti comments favorably on the work. This di Cagliari, 1-11, 1926-27, 189-232; and L. Lazzerini, "Per latinos grossos ... : Studio sui sermoni mescidati," Studi di filologia italiana, xxs. $1971,219-339$

22. On the "subversive significance" of Ruante's and Folengo's works vis-a-vis Bembo, see Paccagnella, 141. For Ruante's criticism of Bembo, see also M. Milani, "Le origini della poesia pavana e l'immagine della cultura e della vita contadina," in Stovia della cultura ieneta (as in n. 20), 37 1. n. 5 .

23. "Phantasia mihi plus quam phantastica venit historiam Baldi grassis cantare Camoenis. Altisonam cuius phamam, nomenque gaiardum terra tremat, baratrumque metu sibi cagat adosstum.
Sed prius altorimm vestrum chiamare bisognat, 10 macaroneam Musae quae funditis artem" (T. Folengo, Baldus, ed. F. Faccioli, Turin, 1989, 2). 24. According to M. Bakhtin. Rabelais and His World (1968), Bloomington, Ind.. 1984, 299-300, Folengo's influence on Rabelais camot be dented but is a superficial one.

95. For the critical reaction to his first edition, sec the following passage in the "Apologetica": "dicet aliquis: Vocabula tingis, O Merline, quibus patria tua solet tantummodo: exempli gratia: doniare puellas." "cimare. "tracagnum," et cetera. quae tantum aut mantanice aut bressanice possumt intel- legi." Pomponazai's theoretical position, as mentioned in Sperone Speroni's Dialogo delle lingue (ca. 1542), is similar. (For the two passages, see $\mathrm{E}$. Bonoma, "L incontro di tradizioni linguistiche nel maccheronico folenghiano," in Retorica e imenzione. Milan, 1970, 81-2.)

26. "Quanto allelegantia toscana. totalmente di Lombardia (non mediantevi lo studio di essa) da natura rimossa" (T. Folengo, Orlandino, Venice. 1526. fol. $91 \mathrm{r}$; ed. M. (hiesa, Padua, 1991, 234).

27. Folengo, 1991 (as in n. 26). 11 .

28. Folengo. Arotmo. Doni, ed C. Cordié, I, Milan/ Naples, 1977.862. 
book - he notes with exquisite irony-should never be lost because such a loss would be far more serious than the loss of the works by Virgil in antiquity and those by Dante and Petrarch in modern times. Indeed, if we had lost the Eclogues, the Georgics, and the Aeneid we would have lost a good poet in one language, but this language could have been handed down in the books of other writers; the same observation can be made of the Tuscan language.

But to lose this book ( $O$ Lord, what a terrible loss), one would have lost a magnificent and very astute writer in many languages, because here the Latin language is woven, the Tuscan language is inlaid, the macaronic language is interlaced. And what is more, [here are] French, Spanish, and German, and even the language used by rascals can here do a good deed and find its place. But what is most important is that this marvelous language belongs to this author alone, and without him is cold, mute, full of mistakes, and wretched, and much worse than eating macaroni with no cheese topping. ${ }^{29}$

Behind Folengo's formal elegance and obvious sarcasm a conscious criticism of the academic discussions surrounding the questione della lingua-as well as an awareness of being on the losing side-is perceptible. ${ }^{30}$

Unfortunately, Folengo's ideological position and the historical interpretation of his thought are not as clear as his open criticism of Bembo's ideas. Indeed, two completely different interpretations of the poet's views have been proposed, their origin lying in the late nineteenth and early twentieth century.

The rediscovery of Folengo dates back to the fundamental history of Italian Literature published by Francesco De Sanctis in 1870-71. De Sanctis assigned an entire chapter to the Benedictine monk, placing it between those dedicated to Ariosto's Orlando Furioso and to Machiavelli. ${ }^{31}$ Subsequent interpretations of Folengo's works were influenced by the debate between "Guelph" and "Ghibelline" critics, a debate which culminated in the two editions published in the prestigious series of the Scrittori d'Italia edited by Benedetto Croce for Laterza. In 1911 Alessandro Luzio edited Maccheronee, or Baldus, emphasizing the secular aspects of Folengo's masterpiece (Luzio's second, revised edition dates from
1927-28). ${ }^{32}$ Between 1911 and 1914 Ugo Renda edited Folengo's Opere italiane in the same series, but he stressed the so-called Benedictine interpretation. ${ }^{33}$

The "secular" position of Luzio, who had studied the "wars of the Benedictine friars" (1901) of S. Benedetto Po in the theological as well as social context, was developed further in an essay by Cesare Goffis (1935). The latter singled out some passages of Folengo's works in which he saw a fiercely anticlerical satire against the immoral behavior of the monks. Goffis did not, however, claim that the writer was attracted by Lutheran thought; rather, he believed that Folengo aspired toward a superior form of Christianity, and that he was part of the wider religious and cultural movement in Italy which condemned corruption within the clergy. ${ }^{34}$

Renda's interpretation, which emphasized Folengo's Benedictine background, thus reducing the poet's scathing social satire to the level of an ordinary difference of opinion between opposing factions of monks, was exhumed by Giuseppe Billanovich, who wrote what remains the most valuable monograph on Folengo (1948). Rich in unpublished documentation, this monograph also countered the theory that the monk had been in ideological opposition to his order. ${ }^{35}$

More recent studies have attempted to build a bridge between these two viewpoints, ${ }^{36}$ but it is the conscious ambiguity of Folengo's language that leaves a certain margin for wildly different interpretations. For the present purpose, however, both the "secular" and the "clerical" interpretation may help, since here it is only necessary to point out a few heterodox aspects of Folengo's thought, together with some facts concerning his troubled and sparsely documented life.

Some of Goffis's claims regarding Folengo's unorthodoxy are by no means overstated: in the toscolanense edition of Baldus, for example, Folengo not only ridicules the practice of selling indulgences, which in 1521 was a dangerous theme to discuss, but also denies that miracles could be attributed to Mary, mother of Christ. To this should be added Folengo's praise of Luther, a section which was eliminated in the last and posthumous edition of the poem, the so-called Vigaso Cocaio published in 1552, as well as his stated admiration for Erasmus. ${ }^{37}$ Moreover, we know that during his period of atonement at Punta Campanella, at the end of the Sorrento peninsula, Folengo was in close contact with the Valdesian
99. "Ma perdersi questo [libro] (o Dio che danno incredibile) si perdeva un bellissimo e ingegnosissimo autore di molte lingue insieme, perché in questa è tessuta la latina, intarsiata la toscana, messa a fregi quella de macharoni. E che piú, che la francese la spagnola, la todesca, e insino a quella de furfanti vi può fare un fioretto e havervi il loco de furfanti vi puo fare un toretto che sopra tut to importa è che questa sí maravigliosa lingua è riposta in questo tale Autore come in specchio e idea di tal idioma, e senza lui è fredda, muta, storpiata e disgratiata, e peggio assai che non sono i macharoni senza caccio" (T. Folengo, Opus Merlmi Cocai. Cipada, 1539-40\% colophon). The language "de' furfanti," that is, the argot of the underworld, is not an invention of Folengo's; he is referring to the "bulesca" literature which takes its name from the 1514 comedy Bulesra. in which the vividly sawr talk of bravos and prostitutes was realistically re-created.
30. Folengo was not, of course, an isolated figure. Similar criticisms of the dominant role given to the Tuscan language could be read in Ruzante's $I A$ Pastoral, written in 1520 , as well as in Matteo Bandello's Novelle, published in 1554 but dating from different periods of his life. For Baldassarre Castiglione, see n. 11 above.

31. F. De Sanctis, Storia della letteratura italiana (1870-71), Naples, It, $1898,46-60$.

32. T. Folengo, Le Maccherompe, ed. A. Luzio (191 I), rev. ed., Bari, 1927-28.

33. T. Folengo, Opere italiane, ed. C. Renda, Bari, $1911-14,2$ vols

34. A. Luzio, "Guerre di frati (episodi folenghiani)," in Raccolta de stude critici dedicata ad Alessandro $D^{\prime}$ Ancona, Florence, 1901, 423-44; and C. F Goftis. Trofilo Folengo: Studi di storia o di poesia. Turin, 1935, passim.

35. Billanovich, passim.
36. See, e.g., M. Chiesa, Teofilo Folengo tra la cella e la piazza, Alessandria, 1988.

37. For these aspects, see Goffis (as in n. 34), 30, $59,83,110$; and C. F. Goffis, "La contestazione religiosa e linguistica nei testi folenghiani," in Cultura, 90. Moreover, Folengo was vehemently opposed to the cult of relics, as the cruel episode of the knife of Saint Bartholomew shows (see $\mathbf{T}$. Folengo, Baldus, bk. 9, ll. 160-375, ed. E. Faccioli, Turin, 1989, 308-19).

38. For Folengo's supposed Nicodemism, see Goffis(as in n. 34), 101 .

39. For the relationship of Gasparo Contarini and Reginald Pole with the congregation, see B. Collett, Italian Bentictine Scholars and the Reformation: The Congregation of Santa Giustina of Padua, Oxford, 1985 .

40. For the origins of Beneficio di Cristo in Pole's circle, see M. Calí, Da Michelangelo all'Escorial: 
group. Although this does not automatically transform Teofilo's feelings into a case of Nicodemism, as Goffis maintains, it is certainly sufficient to demonstrate his real interests during a period when he had not yet been readmitted into the Benedictine order. It is also true, however, that Folengo never expressed open support for the reformation of the Church, and although he entertained hopes for its evangelical palingenesis, he always maintained a low profile. ${ }^{38}$

Archival research by Catholic historians, such as Billanovich and Menegazzo, has on the other hand provided a better-documented picture of Folengo's complex and tormented relationship with the Benedictine congregation of S. Giustina. However, it must be pointed out that these authors underestimated the bonds which linked this Observant order, founded in Padua by Ludovico Barbo at the beginning of the fifteenth century, with two committed reformers, Cardinal Gasparo Contarini and Cardinal Reginald Pole. ${ }^{39}$ The relationship of the congregation with Pole is particularly important because the celebrated and controversial Beneficio di Cristo took shape in Pole's circle: this book was written by Marco Antonio Flaminio, who reworked an earlier text by the Cassinese monk Benedetto Fontanini. The latter was in direct contact with the Folengo family, and Beneficio is very much influenced, both in its language and themes, by the teaching of Juan de Valdes. ${ }^{40}$

As far as Folengo's biography is concerned, it is beyond the scope of this essay to analyze the fictitious aspects which soon embellished Folengo mythology or the troubled events of the monk's family. It is, however, useful to outline the most important known facts of his life up to his dramatic exit from the congregation, since from an analysis of the available records we can surmise that the poet had lived for a long period in the monastery of S. Giustina in Padua, where Girolamo Romanino was also active.

Teofilo Folengo was born in Mantua in 1491. He was the son of the noblewoman Paola Ghisi and of a notary, Federico, who was also a distant relative of the celebrated humanist Vittorino da Feltre. In 1508, when he was sixteen years old, Teofilo entered as a novice the Cassinese monastery of S. Eufemia at Brescia, thus following in the footsteps of his brothers Ludovico, Gian Battista, and Nicodemo, and of his sister Corona, all of whom became members of the congregation of S. Giustina. ${ }^{41}$ The following year he took his vows in the same monastery, and there he remained until the tragic Sack of Brescia (February 1512), later so bitterly evoked in his Zanitonella. ${ }^{42}$ Teofilo then moved to the monastery of S. Benedetto Po, near Mantua, and we know that his father was closely connected with the administration and business operations of this prestigious institution. ${ }^{43}$ Teofilo's elder brother Ludovico, whose misadventures had a fateful impact on the poet's life, also held important positions in this monastery; in 1508 he was elected cellarer and in 1517 (the year of the first edition of Teofilo's Baldus) he became prior. ${ }^{44}$ Unfortunately, after 1512 we are less well informed about Teofilo's movements. In 1959, however, Menegazzo published some important documents which showed that the monk was at S. Benedetto Po on May 18, 1513 , as well as on several occasions during the summer and autumn of 1514 . Indeed, it is the very richness of the documentation during this period (June-October 24, 1514) that calls for an explanation for the silence of S. Benedetto's archival records during the period between May 1513 and June $1514 .^{45}$ Where was Teofilo during those months? An answer may be found in the rule of the Benedictine congregation, which stipulated that some monks should move to other monasteries of the same congregation each spring, immediately following the annual chapters-general of the order. (These mutationes fratrum began in 1444 , and some twenty to thirty transfers were made each year.) The lacuna in the series of documents from S. Benedetto Po, therefore, can help support a hypothesis put forward by Billanovich as early as 1948: according to the latter, in 1513 Folengo spent a prolonged period in the monastery of S. Giustina in Padua, the mother house of the Benedictine congregation. ${ }^{46}$

The fragmentary nature of S. Giustina's administrative books means that this suggestion can no longer be confirmed; nevertheless, the arguments put forward by Billanovich in support of his hypothesis remain valid. In addition to the argument for Folengo's direct contact with the most fertile source of macaronic poetry (a contact which, however, is not indispensable to explaining Folengo's linguistic experimentation), three other points enable one to surmise that Billanovich's hypothesis is probably correct. First, the fact that Teofilo's name does not appear in the list of monks taking part in a meeting at the monastery of S. Benedetto Po on October 11,1513, clearly indicates that he was elsewhere.
Momenti del dibattito religioso nell'arte del Cinquecento, Turin, 1980, 119. E. Menegazzo, "Contributo alla biografia di Teofilo Folengo (151220)," Italia medioetale e umanistira, 11, 1959, 379-80. was the first to identify Benedetto da Mantova with Benedetto Fontanini: his proposal was supported by C. Ginzburg, "Due note sul profetismo cinquecentesco," Riversta storica italiana, I.xxvm, 1966, 196. and later confirmed by $\$$. Caponetto, Il Beneficio $d /$ Cristo con le versioni del secolo XVI: Documenti testimonianze, Florence/Chicago, 1972, 484. On this complex issue and the related extensive bibliography, see C. Ginzburg and A. Prosperi, Giochi $d i$ pazienza: Un seminario sul Beneficio di Cristo, Turin. 1975

41. Unless otherwise stated, Folengo's biographical data are based on Billanovich. Nicodemo was also a poet: see N. Folengo, Carmina, ed. C. Cordié and A. Perosa, Pisa, 1990. R. Signorini, "Un nuovocontributo alla biografia di Teofilo Folengo," in Cultura,
373 , has found evidence ol vet another brother Placido, who entered the Benedictine order.

42. For the text of Zamitomella, see Toofilo Folengo. Macarone minori, ed. M. Zaggia, Turin, 1987. See also M. Zaggia, "Macaronee folenghiane minori: Zanitonella, Moscheide, Epigrammi: Lna nuova edizione," Cirnilta mantorana, no. 19, 1988, 29-36.

43. See E. Menegazo, "Quattro nuovi documenti folenghiani," Atti dell' Istituto L'eneto di Srienze. Lettere ed arti, cxs, $1961-62,505$

44. Menegazo (as in n. 40), 371 .

45. According to the notarial acts published by Menegamo (as in n. 40), 376, Teofilo is documented at S. Benedetto on: Julv 27 and Dec. 4 15l2; Mav 18. 1513; June 4, Aug. 14, Aug. 28, Sept. 23, Sept. 25, and Oct. 24. 1514; Jan. I8 1515. Since the monks would move to another monasterv of the congregation after the chaptersgeneral, which took place in the spring (Billanov- ich, 44), these documents offer a clear pattern of Folengo's movements: he was in Brescia during the first months of 1512; after the sack he moved to $S$. Benedet to, where he staved at least until May 18 ; it is likely that he was in Padua during the "monastic" ear $1513-14$; then he returned to $S$. Benedetto $(1514-15)$; finally, he moved to the Romagna before returning to the monasten of $S$. Eufemia in Brescia in 1519 . On the very interesting institution of $S$. Benedetto Po see, inter alia, $M$. Tafuri, "Osservazioni sulla chiesa di San Benedetto in Polirone," Quadermi di Palazzo Te, no. 5, 1986, 22-23: P. Piva. I." "altro" (Giulio Romano: Il Duomo di Mantora, la chisa di Polirone e la dialettica col Medioez'o, Quistello, 1988; and M. Tafuri, "La chiesa abbaziale di San Benedetto in Polirone 1540 circa sgg.," in Giulio Romano, exh. cat., Milan. $1989,538-44$.

46. For Folengo's Paduan sojourn, see Billanovich, $53-67$. 


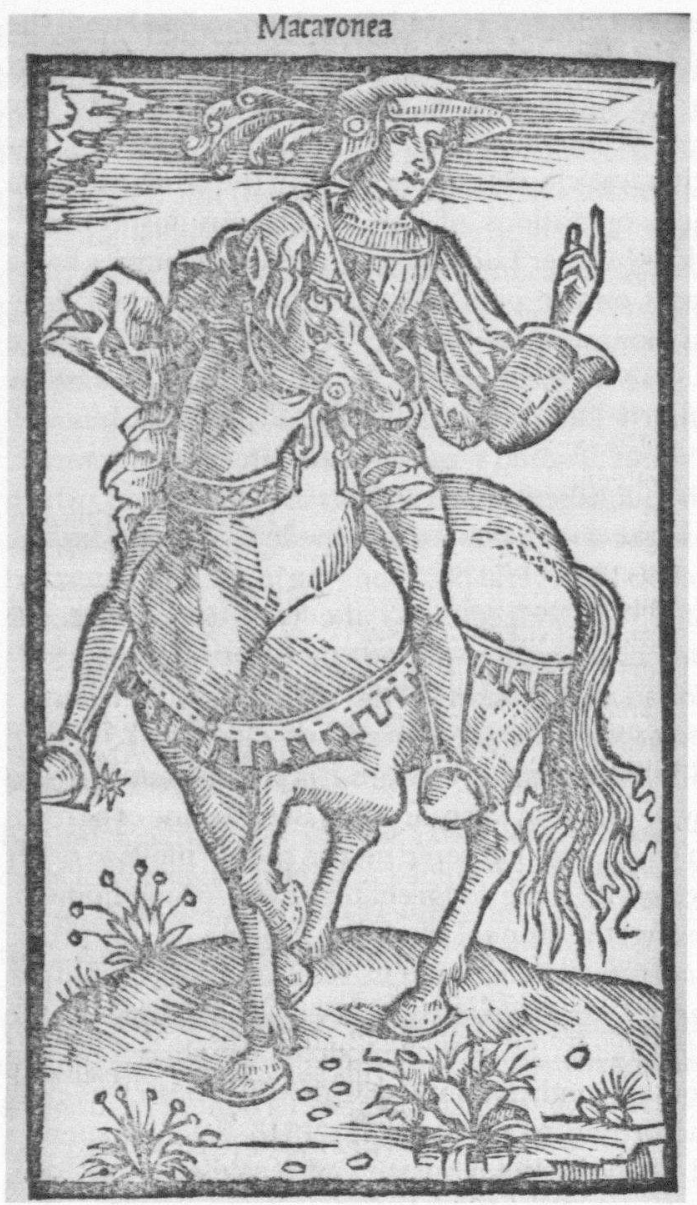

9 Guidone on Horseback. Woodcut from Opus Merlini Cocaii poetae Mantuani Macaronicorum, Toscolano, 1521 (photo: British Library)

Second, the order's requirement that each monk make a prolonged stay in Padua (according to the educational system of the congregation, different disciplines were taught in different monasteries) made a transfer to the most important institution of the order obligatory. Finally, the poet's close acquaintance with Giovanni Cornaro, abbot of S. Giustina in 1513-14, is also well documented; affectionate allusions to this wise and cultivated monk are scattered throughout Folengo's works, and Teofilo could have met him in Padua only during the "monastic" year 1513-14 since Cornaro died in 1515. These observations are so convincing that virtually almost all recent Folengo scholars now assume that the poet was indeed at S. Giustina in 1513-14. ${ }^{47}$

If we accept this, it follows that Folengo and Romanino lived in the Paduan monastery during the same period, since this was when the painter was executing his Last Supper for the refectory, along with his gigantic panel for the high altar of the old church of S. Giustina. The contract for these two commissions, dated April 30, 1513, was published in the nineteenth century, ${ }^{48}$ and research on the relationship between Folengo and the Benedictine congregation (which, incidentally, was one of Romanino's major patrons) has revealed when the altarpiece was completed. According to the "Registro dei morti," now in the Biblioteca Universitaria in Padua, the panel was solemnly inaugurated by abbot Cornaro on July 8, 1514: "Die Sabbati octava mensis Julii MDXIII. In monasterio S. Justinae, D. Joanne de Venetiis abbate ac nostrae Cassinensis Congregationis Praesidente meritissimo, Icona maioris arae erecta fuit, populi magno cum applausu." 49

By the beginning of July 1514 Teofilo Folengo was already back in S. Benedetto Po, but a sojourn at S. Giustina earlier would have enabled him to witness the Brescian artist at work. For the present argument, however, the hypothesis that the painter and the poet actually met is almost irrelevant. What is crucial is that they moved in the same environment because they were both in close contact with Abbot Cornaro.

Since Girolamo Romanino was employed by the congregation of S. Giustina from 1513 till the very end of his life in 1560 , it is not too farfetched to assume that the painter was aware of Folengo's work, and we cannot exclude the possibility that the two continued to know each other. Apart from their probable acquaintance in Padua, it is possible that they could have met in Brescia in 1520, when Teofilo was preparing the second version of his masterpiece in the Benedictine monastery of S. Eufemia. ${ }^{50}$

The toscolanense edition of Baldus (1521) has eight new books, and it also contains many more references to Brescia: "Mantua nos genuit, sed Brixia clara ducavit" (We were born in Mantua, but we were educated in the famous city of Brescia), says one of Baldus's sons in a clearly autobiographical allusion. Moreover, Paganino and Alessandro Paganini, the printers of the first two editions, were closely connected with S. Eufemia. ${ }^{51}$ Clearly, the second edition of Baldus is a Brescian product, and hence it is also likely that the fifty-four woodcuts which illustrate this ambitious book were also designed in Brescia. Since the bizarre drawings were poorly translated by the woodcutter, it is impossible to prove that the designer of these prints was Girolamo Romanino; as is evident from the sheet illustrating Guidone on horseback (Fig. 9), however, the author was obviously an artist active in the area of Milan, Cremona, and Brescia. In the present context one is tempted to connect these prints with Lomaz-
47. See, e.g., N. Borsellino, Gli anticlassicisti del Cinquecento, Rome/Bari, 1973, 65; and the intro. by Cordié (as in n. 28), xxxvi, liii. According to L. Lazzerini, "Baldus di Teofilo Folengo (Merlin Cocai)," in Letteratura italiana: Le Opere, I, Dalle Origini al Cinquecento, Turin: Einaudi, 1992, 1033-64, Folengo was in Padua between 1514 and 1517.

48. N. Baldoria, "Pitture di Girolamo Romanino," Archivio storico dell'arte, IV, 1891, 59-60.
49. Quoted in Billanovich, 1948, 59. But see also G. Bresciani Alvarez, in C. Bellinati and L. Puppi, Padova: Basiliche e chiese, Vicenza, 1975, 122; and L. Attardi, "Girolamo da Romano detto Romanino," in Da Bellini a Tintoretto: Dipinti dei Musei Civici diPadova dalla metà del Quattrocento ai primi del Seicento, Milan, 1991, 113-19.

50. Folengo is documented as being at S. Eufemia in 1519-20: see Billanovich, 69; and G. Billanovich, "Spiritualità e cultura nei monasteri bresciani:
Teofilo Folengo monaco a Brescia," in Folengo $e$ dintorni, Brescia, 1981, 39.

51. The extensive documentation on the Paganini and the congregation of S. Giustina is in Billanov$\mathrm{ich}, 85$, and Billanovich (as in n. 50), 38. On Alessandro Paganini, see A. Nuovo, "La parte veneziana della collezione in -24 di Alessandro Paganino (1515-1516)," in I primordi della stampa a Brescia, 1472-1511, ed. E. Sandal, Padua, 1986. 
zo's mysterious words in his Trattato dell'arte, in which he singled out Romanino for his ability to represent "those figures whose bottom halves are different from their upper parts." 52 It is legitimate to ask why Lomazzo would have used a contorted periphrasis to describe well-known mythical figures such as centaurs and mermaids; and whether, perhaps, he had not found a better way to describe the fantastic creatures which enliven the second part of Folengo's poemor, in other words, those eight books which were added in the second edition: among these fabulous figures, Falchetto, "half dog and half man," is indeed unforgettable. ${ }^{53}$ Such parallels notwithstanding, the unique iconography of the woodcuts and the lack of comparative material definitely executed by Romanino makes a firm attribution to the Brescian artist of these prints difficult, or at least premature.

The important point is that Girolamo and Teofilo were demonstrably part of the same cultural environment. Although it is impossible to prove that they met, the hypothesis that they did is strengthened further by their close association not only with the Benedictine congregation of $\mathrm{S}$. Giustina, but also with the Gonzaga court in Mantua. Once again, a chronological survey produces significant results. An almost forgotten letter addressed to Romanino by Federico Gonzaga and dated July 26, 1519 , reveals that the artist was well acquainted with the Mantuan court. Indeed, even though in his letter the marquis reproached the artist for ignoring the complaints of Paris Ceresara (the court astrologer had commissioned Romanino to paint the façade of his palace), it is also clear that the painter was a well-known and respected figure in Mantua, an artist connected with Federico Gonzaga as well as with Federico's late father, Francesco. ${ }^{54}$

Folengo's connections with the Gonzaga were even stronger. The toscolanense edition of Baldus (1521) was officially approved by Federico Gonzaga, who even consented to cover up one of the poet's deceptions so as to protect him from any possible reprisals by his superiors following its publication; moreover, Orlandino was dedicated to Federico. In addition, the printer of Baldus, Paganino Paganini, was likewise a habitué of the Gonzaga court. We are, therefore, dealing with an intricate network. It is also legitimate to inquire into the marquis's connection with the questione della lingua since, in view of the macaronic experiments carried out in Mantua, he himself may have been personally interested in, or at least curious about, Folengo's linguistic innovations. It should be remembered that the Mantuan court had not yet experienced the brief return of Castiglione in 1523 , the arrival of Giulio Romano in 1524, and the publication of Bembo's Prose in 1525.

The relationship between the Gonzaga and the Folengo is known not to have been enturely amicable. For example, at the time of the peasants' revolt against the monks of $S$. Benedetto Po, Francesco Gonzaga had hoped to transform the possession of the monastery into a large benefice for his son Ercole, who later became a cardinal. Indeed, it was for this reason that Francesco Gonzaga had sided with the opponents of Lodovico Folengo, who was cellarer of the monastery, in 1518. ${ }^{55}$ When Francesco died in March 1519 , however, the relationship between the two families improved. Isabella d'Este, for example, set to work to facilitate the temporary rehabilitation of Ludovico Folengo, who wrote thanking her in March 1520. ${ }^{56}$ Moreover, in the works of Teofilo the allusions to the Gonzaga are as numerous as those to Camillo and Paolo Orsini, who protected him and his brother Gian Battista after their exit from the congregation. In Teofilo's works we find favorable words for Francesco and Isabella, but it is for Federico that the poet reserves his most enthusiastic praise. Zanitonella contains genuine expressions of gratitude toward Federico, who had been able to keep Mantua out of the devastating wars of the period; and, as we have seen, the controversial Orlandino was dedicated to him. ${ }^{57}$ Furthermore, when in 1534 Teofilo was readmitted to the Benedictine order, the president of the congregation thought it appropriate immediately to inform Federico, who was by then duke of Mantua. ${ }^{\text {is }}$

The document which best demonstrates Federico's considerable interest in Folengo's works is a letter he sent to the printer Paganini. In it the marquis assumed full responsibility for the continued printing of the second edition of Baldus, Folengo having fictitiously withdrawn his own copy: in other words, Folengo pretended to remove his own copy of the poem from the printer, and Federico Gonzaga pretended to offer a substitute copy, thus shielding the poet against any possible serious consequences following publication of the manuscript. The text of Federico's letter runs as follows:

To Paganino de Paganinis, our most cherished and excellent friend. Since you are printing the work of Merlino Cocaio [Folengo], and since the author has withdrawn his consent [for its publication], you have asked us to provide a manuscript copy that we have in our possession. We willingly comply with your request, and we send you our copy so that you can continue your work. You will please us and we will have a great opinion of you, if you will print it well and as soon as possible. ${ }^{\text {ig }}$

This letter is dated November 16, 1520. Since Federico's letter to Romanino dates from July 1519 , it is apparent that the painter was traveling between Mantua and Brescia (and of course Cremona) at the same time that Folengo was compiling the second version of his poem. Even more
81-106. It is worth pointing out that in 1517 the Paganini were invited to move to Toscolano by the vicar-general of the Franciscan Observants, Francesco Licheto, who was a patron of Romanino (see U. Baroncelli, La stampa nella vinera bresciama del Garda nei secol $X V^{\prime}$ PVT, Salo, 1964, 19-21; idem. "Tipografi nella riviera bresciana del Carda nei secoli XV e XVI," in Il lago di Garda: Storia di una comeniti lacuale, 1, Salo, 1969, 205; and for Romanino's portrait of Licheto, F. Lechi, I quadri dello collezione Lechi in Brescia: Storia 4 documenti, Florence. 1968, 155)

52. G. P. Lomazo, Sortti sulle arti, ed. R. P. Ciardi, Florence, 1973, If, 409

53. Folengo (as in n. 23), bk. 16. 1. 389, ed. F. Faccioli, Turin, 1989. 536

51. A. Luzio, La Galleria dei Gonzaga ienduta all'Inghiltem nel 1627-28, Milan, 1913, 225.

55. These events are well summarized in R. Si gnorini, ed.. Folengo perche. Mantua, 1977, 24.
56. For the relationship between Federico Folengo and the (ionzaga, see Menegarzo (as in n. 40), 369 For Ludovico's leter, see Signorini (as in n. 55), 24 57. For Zamitonolla, see E. Bonora, "Vita mantovana nelle Maccheronee," in Cultura, 18-19; and Zaggia, 1987 (as in n. 42).

58 . See Signorini (as in n. 55), 26 .

59. Ibid.. 23, fig. 19. 
important, however, is the fact that Romanino and Folengo shared the same patrons: the congregation of S. Giustina and the Gonzaga.

If, on the basis of a study of their respective chronologies and of the circles in which they both worked, it is legitimate to interpret the works of Folengo as the "literary equivalent" of Romanino's heterodox style, it is crucial to avoid any possible misunderstanding; by no means should the style of Romanino's painting between the $1520 \mathrm{~s}$ and the $1540 \mathrm{~s}$ be viewed as a sort of pictorial macaronic language. Folengo's linguistic experimentation could rely upon a rich local tradition; Romanino, on the other hand, questioned the classical canon by introducing into his paintings elements borrowed from contemporary German art. Yet this comparison between the works of the two Lombard natives may help us understand the motivations behind Romanino's remarkable stylistic transformation. Indeed, in their attempt to undermine or at least challenge the High Renaissance canon, as best represented in the north of Italy by Bembo and Titian, with their heterodox experiments both Folengo and Romanino shared the same intellectual goals. Far from being the product of "provincial" artists unable to maintain the pace of their more distinguished colleagues, Folengo's and Romanino's works were conscious statements made during a crucial and extremely ambiguous period in Italian cultural history.

The possible relationship between Romanino and Folengo has never been investigated, but scholars have already pointed out the similarities between the grotesque language used by Romanino in some of his late works and the vocabulary of another anticlassical writer, Galeazzo dagli Orzi, author of the oldest known work written in the Brescian dialect: La massera da bé (The good housewife). ${ }^{60}$ These generic comparisons, however, have been put forward in total isolation, and without taking into account the broader network of Italian anticlassicism and its related social environment. It is not surprising, therefore, to discover that these heterodox experiments have always been interpreted as the product of marginalized authors. Even those few critics who understood that an evaluation of Romanino's work could not be separated from an interpretation of his linguistic choices could not help emphasizing the "popular inclination" of the artist. $^{61}$ It is in this context, therefore, that the results achieved by literary historians in their investigations into the questione della lingua should be examined.

Folengo's works and linguistic experiments have at times been misunderstood as merely impertinent parodies of aulic models. It should, however, be understood that the language Folengo developed not only achieved comic effects through the idiosyncratic combination of Latin structures and terms borrowed from various dialects, but also that it was above all the expression of a literary maverick, an instrument designed to undermine the norm established by Pietro Bembo. Folengo's creative idiom was the result of the writer's impatience with an official language unable to provide a suitable vocabulary for the themes the Benedictine monk chose to discuss. These themes focused primarily on the chaos of everyday life observed in its most material and unpleasant forms, with all its grotesque and scatological overtones. ${ }^{62}$ Yet this "earthy" view of the world was far from displaying any sympathy for the poor and underprivileged. Folengo's texts had very little to communicate to ordinary people, and in fact the poet's public was an extremely cultivated one. Indeed, as has been demonstrated by two eminent classicists, his hexameters were based on a flawless prosody. ${ }^{63}$

After what has been stated above concerning the possible relationship between Folengo and Romanino, it is perhaps not too farfetched to read the painter's grotesque expressionism in a similar way. Romanino's anticlassical elements emerged around 1519-20 when Folengo was preparing the second edition of Baldus, and even if we cannot prove that the painter designed the woodcuts illustrating that edition, it is at least tempting to interpret Romanino's stylistic change as a conscious and cultivated critique of the canon that Titian had established. The interpretation of Romanino as an artist concerned about the condition of the poor and underprivileged is not convincing; neither does the theory of a total intellectual isolation due to his heterodox interests seem plausible, at least as far as the first decades of the sixteenth century are concerned. Writers and painters such as Folengo and Romanino lost the battle not because they represented a lower social group, but because they tried to undermine a body of rules which had been imposed by the classical canon.

From a late twentieth-century point of view, this may seem a strange and almost suicidal choice, but it is likely that around 1520 such a stand was not perceived by Romanino as a route leading to the intellectual isolation in which he eventually must have found himself. Indeed, artists such as Folengo and Romanino moved, at least during this crucial period, in highly sophisticated circles which must have been genuinely interested in, although possibly puzzled by, their works. It is essential to understand that during the first decades of the sixteenth century the final outcome of the struggle over the definition of a linguistic canon was quite uncertain. The formal experiments of writers and painters such as Folengo and Romanino were carried out during a period when many cards had still to be played, and those who adopted the so-called anticlassical position did not yet know that they were enlisting in the losing team. These were extremely confused years, and it is not at all easy to unravel the different strands of a very complex game in which political aspirations, linguistic experiments, and religious reforms were interlinked. Only a comparative study from all these points of view, which sooner or later must be carried out with the cooperation of many different specialists and according to a strict chronological sequence, will provide answers to some of these questions.

Among the most urgent desiderata for sketching a plausible comparative history of the first twenty-five years of the sixteenth century in northeast Italy are: detailed catalogues raisonnés for all the heterodox artists of the period, thus complementing what is already known about the major figures (Giorgione, Titian, Giovanni Bellini, Sebastiano, etc.); a comprehensive survey of all the illustrated books printed in the area between Brescia and Venice; a monographic treatment of the circulation of German books and prints in the territories of the Dominante; an analysis of the 
patterns of patronage, and more specifically of the networks created by the mendicant and monastic orders with their specific religious interests; lastly, a philological reexamination of all the texts which deal with the linguistic issue. Given the limited scope of this essay, it is sufficient to point out (as an example of the complexity of those vibrant years) that before the publication of Bembo's Prose the classical norm was far from being universally accepted, and that anticlassical writers could rely upon a faithful and loyal audience. ${ }^{64}$ The first edition of Folengo's Baldus, for example, was so well received that two pirated editions were published in Venice and in Milan in 1520, if we can trust Teofilo's own words. Similarly, although Romanino was later forced to work for minor centers in Valcamonica, he did not immediately lose the support of important patrons. In other words, Folengo and Romanino were undoubtedly eccentric and rebellious, but initially at least they were not entirely marginalized.

In the late 1520 s, however, the situation in Northern Italy underwent a radical transformation: in 1524 Giulio Romano moved to Mantua; after having published his Prose in 1525, Bembo worked hard to impose his rules on Italian literary circles; and during the same period Clement VII initiated investigations into the circulation of supposedly heretical books. Within a few years the operational margin of heterodox intiatives was drastically reduced. Although Folengo later published a third, revised edition of his great poem, in 1534 he rejoined the congregation of S. Giustina, and his last works were written in Tuscan and in Latin. ${ }^{65}$ It was in this changed and undoubtedly more dangerous climate that Romanino was forced to accept the commissions of communities in Valcamonica; or perhaps he felt that only in such a remote area, well known for its heterodox religious inclinations, could he continue his formal experiments.

In the late 1540s Romanino's partnership with his son-inlaw, Lattanzio Gambara, gave a new direction to the last works of the old Brescian master. Following a period of study with the Campi in Cremona, Gambara imported the language of the Maniera into Brescia, thus providing Romanino with a new linguistic idiom. The result was that Romanino's paintings once more became fashionable with the Brescian élite. Nevertheless, the glorious period of anticlassical experi- mentation, when Romanino and some of his colleagues such as Altobello Melone dared question the rule imposed by the classical canon, was forever over.

To conclude, it should be noted that as historians we tend to build our narratives as a more or less clear chain of events; taking advantage of our hindsight, we separate what is "important" from what is "marginal." This is a reasonable approach, and as far as the present issue is concerned, nobody would question that Titian was infinitely more influential than Romanino in the subsequent history of Western painting. Yet it is unlikely that we can fully understand how the center took its shape if we do not also examine the margins. A history of sixteenth-century Italian painting can no longer be written by isolating the achievements of the most important artists from the issues that were debated around them and in opposition to their views. To quote from an essay by Dante Isella, who elaborates a suggestion by Carlo Dionisotti: "to write a history of [Italian] literature means to investigate the complex relationships between the different cultural centers of the peninsula and of the continent in their different chronological phases, and to understand the game of thrusts and counterthrusts on which that history is built." 66

The history of Italian art is still reluctant to follow such a path.

\section{Frequently Cited Sources}

Billanovich, G., Tra don Teofilo Folengo e Merlin Cocaio, Naples, 1948.

Cultura Cultura letteraria e tradizione popolare in Teofilo Folengo, Atti del convegno di studi (Mantua, 1977), Milan, 1979.

Dionisotti, C., Gli umanisti e il zolgare fra Quatrocento e Cinquesento, Florence, 1968.

Paccagnella, I., "Plurilinguismo letterario: Lingue, dialetti, linguaggi," in Letteratura italiana: I, Produzione e consumo, Turin: Einaudi, 1983, 103-67.

Alessandro Nova, assistant professor of Renaissance art at Stanford University is the author of a book on the patronage of Pope Julius III (1988) and of a forthcoming catalogue raisonne of the paintings of Romanino. He has uritten extensively on Italian art of the fifteenth and sixteenth centuries [Department of Art, Stanford University, Stanford, Calif. 94305-2018].
60. La massera da bé was first published in Brescia in 1554 as the work of an anonymous author: see the intro. by G. Tonna to G. Dagli Orzi, La massera da bé, Brescia, 1978, 13-15.

61. See, e.g., G. Testori. Romanino e Moretto alla Cappella del Sacramento, Brescia, 1975, 7. Testori is the only scholar to have understood that the heterodox language "spoken" by Romanino is a crucial element in the artist's work; see also (c. Testori, "Giacomo Ceruti (lingua e dialet to nella tradizione bresciana)," in Giacomo Ceruti: Mostra di 32 opere inedite, exh. cat., Milan, 1966, v-xxxi). It is no coincidence that Testori himself belonged to the
Lombard plurilinguistic tradition, which had its roots in the macaronic experimentation: see the intro. by G. Contini to C. E. Gadda, Cognizione del dolore. Turin, 1970 (repr. in G. Contini, Jarianti e altra linguistira. Turin, 1970, 603-19); C. Segre, "I a tradizione macaronica da Folengo a Gadda (e oltre)" in Culturi, 68; and Paccagnella, 147. All these authors point out the impact of the old Lombard-Paduan language on Iestori's tragic trilogy (Ambleto, Macbetto, Edipo)

62. For Folengo's anti-Bembo position, see (i. Folena. "Il linguaggio del Caos." Cultura, 23x; and Paccagnella, 109.
63. L. E. Paoli, "Per una futura edizione delle Maccheronee del Folengo: Osservazioni di critica del testo," Giornale storico della letteratura italiana, (xII, 1938, I-51; and E. Paratore, "Il maccheroneo Colenghiano," in Cultura, 38.

64. According to Folena (as in n. 62). 234, Bembo was rather isolated before the publication of his Prose.

65. See Chiesa (as in in. 36), 112

66. D. Isella. "La cultura lombarda e la letteratura italiana," Culture regionali e letteratura nazionale, Bari, 1970,57 